\title{
Municipal Awareness as an Integral Part for Enhancing Citizen Satisfaction of Malaysian Municipal Councils, Batu Pahat
}

\author{
Muhammad Umar Bello ${ }^{1,2}$, David Martin @ Daud Juanil ${ }^{1}$, Rozilah Kasim ${ }^{1}$ \\ ${ }^{1}$ Universiti Tun Hussein Onn Malaysia \\ 101 Parit Raja, Batu Pahat, Johor, 86400, Malaysia \\ ${ }^{2}$ Abubakar Tafawa Balewa University \\ Tawafa Belewa Way, P. M. B. 0248, Bauchi, 740272, Nigeria
}

DOI: $10.22178 /$ pos. $24-2$

JEL Classification: H75, I38

Received 15.06.2017

Accepted 10.07.2017

Published online 14.07.2017

Corresponding Author: Muhammad Umar Bello, mubello78@gmail.com

(c) 2017 The Authors. This article is licensed under a Creative Commons Attribution 4.0 License (c) (1)
Abstract. This research study critically analysed the existing literature on municipal awareness relevancy of municipal councils' service delivery for the purpose of enhancing citizen satisfaction. The purpose of the study is the investigation of citizen satisfaction level of municipal services through the use of municipal awareness. The Material and methods were carried out using secondary data and were meticulously and critically analysed to come up with reliable results. The study shows the relevance of the public awareness, citizen satisfaction and municipal council performance in Malaysia. It is evidence in the research that citizen consent is important before municipal services should be provided in the local community.

The research study highlighted many discrepancies in many kinds of literature related to the existing research study, evidence-based analysis were carried out to buttress importance and significance of the related study to the research work. The literature was reviewed to ascertain the current happening in the area of municipal council service delivery. The study shows that many municipal councils in Malaysia provide adequate and satisfactory services to their citizens'. The results of the study also revealed that municipal awareness plays an important role on citizen satisfactions of municipal service delivery. It is also evident that adequate provision of services has direct bearing with municipal councils. The study concludes that municipal service delivery can be enhanced through citizen awareness campaign, to sensitise the local community on various aspects of service delivery including maintenance of the facilities provided. The study also concludes that local Authorities lack of awareness section affects their performance in service delivery process. The study recommends that municipal councils need to consults the citizen for their needs and wants; awareness campaign needs to be regularly carried out to maintain cordial relationship between local Authorities and their citizen; it is also recommended that municipal services should be delivered the needed services by the local inhabitants' after duly consultation.

Keywords: municipal awareness; municipal council; local authorities; citizen satisfaction.

\section{Introduction}

Municipal council in Malaysia is observed as a foundation for overall community advancement $[40,41,55]$. The prominence of municipal council cannot be over stressed it will stem from increas- ing role in local development and sustainable development programmes. However, successful municipal council has been identified as essential to meet the sustainable development goals, which implies a stronger role for local authorities 
and municipalities in local development [24, 85, $67,87]$. This includes methods of investing in municipal council and promoting citizen awareness of local affairs in order to foster transparency, accountability and responsiveness of local authorities, and in turn, increase citizen satisfaction with municipal service and outcomes. Within this background, there is continue advocacy of enlighten local community on municipal council affairs to foster their satisfaction. This modification in focus changed the attention towards the subtleties of local communities and citizens with the significance of their engagement in local affairs and service assessment. This role is essential for improving municipal services, as municipal council are the adjoining level of government to citizens and their interactions and outcomes have significant impacts on citizen's daily survival $[13,23,39,89]$. In other word, citizen awareness of and participation in municipal affairs are importance instruments for aligning municipal outcomes with the needs and wants of local communities. Citizens' awareness of municipal activities', would improve citizen support for municipal service outcome. Municipal council service outcomes mainly represented by municipal services are often constrained by the lack of knowledge about the local processes and procedures among the public [9]. Municipal awareness plays a vital role in citizen attitude toward the local Authorities (LA), performance measurement of LA's activities can be ascertained based on the citizen awareness. In this regards, how they respond to the authorities' demand showcase the level of municipal council development attainment [32, 52]. Whereas, well-designed social audit mechanisms and positive citizens' perception of service delivery are critical for effective municipal performance and municipal populace awareness [55].

Municipal awareness is of different grades; political awareness, regulation awareness, environmental awareness, planning awareness. All these levels of awareness have a positive impact on the development of LA's service delivery. Citizen awareness of municipal council activities and operations through media interventions, and public campaigns and forums can promote the capacity of citizens to advocate for their interests and hold local officials accountable for their decisions and activities. Increasing citizen awareness of municipal matters is an effective tool for promoting citizens' engagement and improving service delivery [37]. D. Pretorius, W. Schurink [63] asserted that rapid municipal development fuelled by the world economical ideologies and technology have been forcing public sector to transform their leadership in order to become more responsive and competitive. These statements emphasize that good leadership are needed to improve municipal awareness and citizen satisfaction for service delivery in municipal council, adjust to the ever-changing demands of local authority as well as address the inequalities of the past [73].

Moreover, municipal council needs to change from a merely institutional entity to a more developmental organization where citizen awareness would be enhancing for citizen satisfaction [17]. Machinery to achieve these objectives are not embedded and in the external establishment sphere (public-private partnerships and small, medium and micro enterprises), but also in the guidelines and conditions of service, and the quality of local authorities' staffs and sustainability of the working environment. More again, a municipality is an indispensable foundation in the local level through the numerous services it provides for local inhabitants; and through its direct communication with citizens within its land mass jurisdiction. S. Almarshad [9] stress that appointment of citizens in municipal council service delivery development kindles local authorities to take care and efforts on commencing more ambitious plans for citizen participation and growing public access to municipal services.

More again, municipal awareness as a mechanisms for citizen satisfaction was acknowledge by [47]. Citizen satisfaction can be reached when the local inhabitants are aware of affairs of the LA's. A. Ramachandra, N. Mansor [65] and Y.Zamzami [91] highlights the importance of citizen interaction and community involvement in the management and the evaluation of local programs and activities to avoid random municipal planning and implementation that would result in undesirable local outcome.

Problem statement of the research. Citizen lack of awareness of the administration of municipal council is the major hindrance to the development of the municipal council areas and the inhabitants [22, 30, 84]. Responsiveness of citizen towards the local authorities' service delivery are determined by the level of citizen awareness [9, $18,26,72]$, citizen satisfaction in Malaysian public sector were given attention especially in municipal councils has indicated by [43], local au- 
thorities inhabitants need and wants are attended unsatisfactorily [78] and [27]. Awareness of citizen on the outcome of local authorities' performance outcome may foster cordial understanding. Lack of government commitment towards satisfying municipal council inhabitants necessitated this study. Creation and establishment of required information can empower local authority with benefits of citizen compliance of their regulations $[9,91]$ and $[20,90]$, against this background awareness of citizen on the performance of local authorities in many countries of the world are based on the seriousness of the government official to enlighten their citizens. Thus, one of the exceptional issues of local authority in Malaysia is that there is no adequate information channel to the citizens. Furthermore, many interests of the citizens are not fully represented in the higher level of decision making of the local councils. In some cases, there is strong political interference in local authorities that affects their actions and decisions.

Many researches has shown that there are various factors impart in creating citizen awareness, satisfaction and sense of belongingness toward brands of any kind but sometimes customers themselves are unaware of the reasons for the brand preferences [33]. In the contemporary time the only constant agent is change. LAs positive change towards advancement of service delivery and information dissemination among the inhabitants enhance the LAs position in terms of provisioning of municipal services. H. Ofoeze [56] assertion is that municipal council areas are created to solve rural developmental problems and to provide services at satisfactory level. Services such as street sweeping, grass cutting, parking space provisioning etc. are required to be provided and maintained by both the LAs and the citizens' [34] and [54], With the marvelous increase in population connected a municipality [10], LAs are the bedrock of development of local people and monitoring wing of social justice [11, 12, 14, 43, 84].

Literature review. There are limited literature on citizen awareness for enhancing citizen satisfaction of municipal service delivery. This study tries to highlight the important of citizen awareness in municipal council service delivery (Figure 1).

Citizen awareness. Citizen awareness is very important concepts because it involved understanding and participation of citizen $[10,83]$.
Municipal Awareness

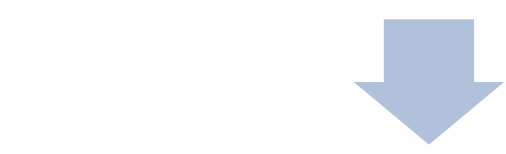

Citizen Awareness, Political Awareness, Environmental Awareness

Citizen satisfaction

Figure 1 - Conceptual framework of the study

Citizen awareness has been characterized as having ties to the need and wants to the developmental services within their local territory [16, $49,88]$. Citizen were concerned about their local community development and this give them a deep awareness of municipal council administration appreciation for services needed, and sense of responsibility and participation as stakeholder [48]. The awareness of this concept was expressed by mobilisations in favour of municipal service development [48, 73]. Meanwhile, the councils of municipal council, civil society organizations, political parties [and] donor agencies all participate in the preparation of village/district profiles, preparation of Periodic Plans, and determination of development priorities, an assessment of the people's present information literacy capabilities is crucial $[1,2,3$, 36]. More again, B. Holmes [35] suggested that the concepts of public awareness is encompasses behavioural and psychological dimensions that will enable citizen perceptions to determines the performance of municipal council service delivery. Citizen awareness or Civic awareness is splinter of a constant interaction process between the local authorities, populace and organised civil society. This awareness process is classified in terms of the combination of all the community organizations, taking the form and status of social partners through social work, education, public engagement, and the values of basic rights.

Political awareness. Political awareness are means of citizen understanding of political affairs of their locality, the headship of municipal coun- 
cil was charge to create resources of public enlightenment towards the municipal process of service delivery $[4,5,6,69]$. Management of municipal council expressively should be keen in obliging any policy that will improve the process of municipal service delivery $[42,43]$. Creation of mechanism to enlighten the inhabitants on issues related to their life and wellbeing is the main function of municipal council officials. Political awareness by the nationals' and peoples enable them understand their condition and direction of the local council. Criticisms and grievances' can be channelled properly to the municipal council $[19,77]$. Many scholars linked citizens' satisfaction with the awareness of the local communities on the services delivered and their expectations on the performance of the municipal council [50, $53,64,81]$.

\section{Environmental awareness. Environmental} Awareness becomes an issue of increasing concern since last two decades, particularly in western economies [60] and [86]. This concern has been shared not only by environmental groups and legislators, but also by customers, local communities, public authorities, suppliers, financial institutions and employees [21]. As a result, there has been increasing pressure for municipal administration to improve their environmental management activities and practices in order to enhance citizen satisfaction [31]. Local community need to be environmentally aware so that the service provisioning can be effectives [61]. In fact, many municipal councils have deficiency in enlighten their local communities so that they can be enlighten. M. Sengupta, J. Das, P. Maji [75] and M. Akhter, Y. Dwivedi, V. Kumar, U. Kumar [7] revealed that an environmentally accountable citizen and community in addition to having awareness should have rudimentary understanding of the environment and its hitches, feelings of apprehension for the environment, expertise and inspirations to solve and ultimately, partake in environmental development programs.

Citizen satisfaction. Since about three decades ago Sweden developed and became the first country in the world to established standardized cross company and cross industry methodology of measuring customer satisfaction and customer loyalty [70]. This general and national measurement gadget for customer satisfaction and customer loyalty is called the Swedish Customer Satisfaction Barometer (SCSB). Satisfaction of municipal services is one of the major evaluation of LAs service delivery performance [15]. LAs per- formance must commiserate with citizen satisfaction of municipal services provisioned by local council, satisfaction of citizenry should be main target of municipal council officials. To makes a meaningful development within the demarcation of local council, the needs and wants of the inhabitants' fulfilment represents the activeness of the local councils. In Malaysia the position of local councils allow them to take the responsibility of providing services to the local community [46, $68,71,83]$. If the municipal services delivered by the local councils are perceived as poor, the future of good governance and professional images of this local councils will be at stake [71]. Malaysian federal government set aside large sum of money for local community development services [59].

\section{Materials and Methods}

Information or data that are collected and used in this study were extracted from secondary sources of data which comprised of textbooks, articles, thesis and statutory documents. The data were critically reviewed to ascertain the current happening in the area of municipal council service delivery. Mostly, the journals that were reviewed adopted quantitative methods and they adopted Structural Equation Modelling (SEM) for their final data analysis. It must be emphasised here that the method adopted for data collection in this study is a literature review analysis. Upon extracting data from the review, inferences will be drawn on municipal awareness for enhancing citizen satisfaction of municipal services in municipal council in Malaysia.

\section{Result and Discussion}

The result of this research study revealed that municipal council in Malaysia provide adequate and satisfactory services to their citizens, but need additional efforts as it was evident in the work of $[29,59,58,51]$. The authenticity of this research work is verified thoroughly, and the results vindicated that similar research come to agree with the conclusion of the results of this research work in many respects. The works of [9] and [80] indicates that awareness of citizen is integral part of process of assessing government performance, this also agrees with the final result of this research work. Municipal service qualities are determined by how informed and their quality of life, the study of $[38,66]$ also agree with the 
finding of this research work. This particular study did not agree with the research of [44] that emphasised that municipal awareness is among the key indicators for satisfactory service delivery. Findings of this research revealed that municipal awareness can be enhance by creating an independent section for information and enlightenment $[8,25,79]$.

The findings of this study come into agreement with [28], citizen satisfaction is related to the level of citizen awareness as opined by [40] and [59]. The satisfaction of vulnerable group among the citizen in many municipal councils in Malaysia are giving more concerned as vindicated by [51]. But creation of awareness team within the municipal councils' staffs would be of help to the communities has revealed in [17]. Municipal councils create enabling environment for citizen satisfaction of quality municipal services for the betterment of local communities [76], it was disagree in India that awareness of citizen plays an important indicator for citizen satisfaction in healthcare service delivery [45]. Finally, this research comes to assent with most literature that municipal awareness plays an important role in attaining comprehensive citizen satisfaction.

\section{Conclusions}

This research work concluded that municipal services delivery can be enhance through citizen awareness campaign, to sensitise the local community on various aspects of service delivery including maintenance of the facilities provided. It is also concluding that LAs lack of awareness section affects their performance in service delivery. It was also concluded that local community need to be aware of the process of service delivery and all what it takes to get satisfaction. It was evident that enlightenment of municipal residents, it's imperatives to accommodate service users through informing them the issues that municipal councils intend to address in the given financial year. Peoples are contented mostly with the performance of their municipal councils, most especially in the aspects of public toilet provisioning as evident by [15]. The significance of municipal awareness was highlighted to ascertain the improvement of citizen satisfaction in the municipal councils. In order to enhance citizen satisfaction in municipal councils the management should employ ad hoc staffs if a reasonable projects need to be executed. The study recommended that municipal councils need to make strong consultations of the citizen for their needs and wants; awareness campaign need to be regularly carried out to maintain cordial relationship between municipal councils and their citizen; it is also recommended that municipal services should be delivered after duly consultation with the local communities.

\section{Acknowledgement}

The authors would like to acknowledge the support, assistance and guidance given by his $\mathrm{PhD}$ supervisor through constructive criticisms and suggestion in the conduct of the research, and also to his co-supervisor. The authors are also grateful to the previous literature research that has been made in any anonymous journal arbitrators related to municipal service delivery and citizen satisfaction. The authors also show their indebtedness to Office for Research, Innovation, Commercialization and Consultancy Management (ORICC) UTHM, Batu Pahat, Johor, Malaysia.

\section{References}

1. Aagesen, G. (2012). Multi-channel Provisioning of Public Services (Doctoral thesis). Retrieved from http://brage.bibsys.no/xmlui/handle/11250/252859

2. Abe, T., \& Monisola, O. J. (2014). Citizen Participation and Service Delivery at the Local Government Level: A Case of Ise/Orun Local Government in Ekiti State, Nigeria. Journal of Law, Policy and Globalization, 27, 102-110.

3. Abid, A. (2004). Information literacy for lifelong learning. In World Library and Information Congress: 70th IFLA General Conference and Council, 22-27 August 2004, Buenos Aires, Argentina. Retrieved from http://www.ifla.org/IV/ifla70/papers/116e-Abid.pdf

4. Adeyemi, O. (2013). Local Government and the Challenges of Service Delivery: the Nigeria Experience. Journal of Sustainable Development in Africa, 15(7), 84-98. 
5. Agba, M. S., Akwara, A. F., \& Idu, A. (2013). Local Government and Social Service Delivery in Nigeria: A Content Analysis. Academic Journal of Interdisciplinary Studies, 2(2), 455-462. doi: 10.5901/ajis.2013.v2n2p455

6. Aijaz, R. (2007). Challenges for Urban Local Governments in India. Retrieved from http://eprints.lse.ac.uk/25190/1/ARCWorkingPaper19RumiAijaz2007.pdf

7. Akhter, M., Dwivedi, Y. K., Kumar, V., \& Kumar, U. (2016). Reformation of public service to meet citizens ' needs as customers: Evaluating SMS as an alternative service delivery channel. Computers in Human Behavior, 61, 255-270. doi: 10.1016/j.chb.2016.03.002

8. Alfarraj, O., Chelliah, P., Thurasamy, R., Alzahrani, A., \& Alalwan, N. (2016). E-Government Service Delivery by a Local Government Agency: The Case of E-Licensing. Telematics and informatics, 33(4), 1-23. doi: 10.1016/j.tele.2016.02.003

9. Almarshad, S. O. (2011). The Impact of Good Governance and Decentralization Reforms on the Effectiveness of Local Authorities: The Case of Saudi Municipalities (Doctoral dissertation). Retrieved from http://digitalcommons.uconn.edu/dissertations/AAI3451394/

10. Almarshad, S. O. (2015). Municipal Awareness and Citizen Satisfaction: The Case of Northern Borders in Saudi Arabia. International Review of Management and Marketing, 5(2), 94-101.

11. Amin, M., \& Isa, Z. (2008). An examination of the relationship between service quality perception and customer satisfaction: A SEM approach towards Malaysian Islamic banking. International Journal of Islamic and Middle Eastern Finance and Management, 1(3), 191-209. doi: 10.1108/17538390810901131

12. Andrews, R., Boyne, G. A., Law, J., \& Walker, R. M. (2005). External constraints on local service standards: The case of comprehensive performance assessment in English local government. Public Administration, 83(3), 639-656. doi: 10.1111/j.0033-3298.2005.00466.x

13. Angelidou, A. M., \& Psaltoglou, A. (2017). An empirical investigation of social innovation initiatives for sustainable urban development. Sustainable Cities and Society, 33, 113-125. doi: 10.1016/j.scs.2017.05.016

14. Antuono, L., Meeks, C., Miller, M. K., \& Watchou, J. R. (2006). Evaluating NGO Service Delivery in South Asia: Lessons for Afghanistan. Retrieved from http://www.lafollette.wisc.edu/images/publications/workshops/2006-servicedelivery.pdf

15. Anwer, M. A., Esichaikul V., Rehman, M., \& Anjum M. (2016). E-government services evaluation from citizen satisfaction perspective. Transforming Government: People, Process and Policy, 10(1), 139-167. doi: 10.1108/TG-03-2015-0017

16. Bache, I. (2013). Measuring quality of life for public policy: an idea whose time has come? Agendasetting dynamics in the European Union. Journal of European Public Policy, 20(1), 21-38. doi: 10.1080/13501763.2012.699658

17. Bagstad, K., Johnson, G., Voigt, B., \& Villa, F. (2013). Spatial dynamics of ecosystem service flows: a comprehensive approach to quantifying actual services. Ecosystem Services, 4, 117-125. doi: 10.1016/j.ecoser.2012.07.012

18. Barnes, M. (1999). Users as citizens: collective action and the local governance of welfare. Social Policy and Administration, 33(1), 73-90. doi: 10.1111/1467-9515.00132

19. Blaug, R., Horner, L., \& Lekhi, R. (2006). Public Value, Citizen Expectations and User Commitment: A Literature Review. Retrieved from https://www.researchgate.net/publication/253726604_Public_value_citizen_expectations_and_ user_commitment

20. Borins, S. (2012). Innovation in business and government: Looking forward. Retrieved from https://coombs-forum.crawford.anu.edu.au/publication/hc-coombs-policyforum/2493/innovation-business-and-government-looking-forward 
21. Bubna-Litic, K., \& De Leeuw, L. (1999). Adding the Green Advantage: A Survey of Australian SME's. Retrieved from https://gin.confex.com/gin/archives/1999/papers/SUadding.pdf

22. Callahan, K. (2002). The utilization and effectiveness of citizen advisory committees in the budget process of local governments. Journal of Public Budgeting, Accounting and Financial Management, 14(2), 295-319.

23. Carter, N. (1991). Learning to measure performance: the use of indicators in organizations. Public Administration, 69(1), 85-101. doi: 10.1111/j.1467-9299.1991.tb00783.x

24. Crespo-Gonzalez, C., Garcia-Cardenas, V., \& Benrimoj, S. I. (2017). The next phase in professional services research: From implementation to sustainability. Research in Social and Administrative Pharmacy, 30, 1-6. doi: 10.1016/j.sapharm.2017.05.020

25. Cuadrado-Ballesteros, B., García-Sánchez, I.-M., \& Prado-Lorenzo, J.-M. (2013). Effect of modes of public services delivery on the efficiency of local governments: A two-stage approach. Utilities Policy, 26, 23-35. doi: 10.1016/j.jup.2013.04.005

26. Darison, A.-H. B. (2011, September). Enhancing local government revenue mobilization through the use of information communication technology: a case-study of Accra Metropolitant Assembly (Master thesis). Retrieved from http://ir.knust.edu.gh/xmlui/bitstream/handle/123456789/2156/DARISON\%27S\%20thesis.p df?sequence $=1$

27. Dewulf, G., \& Meel, J. (2002). User participation and the role of information and communication technology. Journal of Corporate Real Estate, 4(3), 237-247. doi: 10.1108/14630010210811868

28. Di Giulio, M., Galanti, M. T., \& Moro, N. F. (2016). Political coalitions, local leaders and the internationalization of local public services in Italy. Utilities Policy, 40, 144-151. doi: 10.1016/j.jup.2016.01.008

29. Donnelly, M., Wisniewski, M., Dalrymple, J., F., \& Curry, A. C. (1995). Measuring service quality in Malaysian local government: the SERVQUAL approach. International Journal of Public Sector Management, 8(7), 15-20. doi: 10.1108/09513559510103157

30. Ebdon, C. (2002). Beyond the public hearing: citizen participation in the local government budget, process. Journal of Public Budgeting, Accountability and Financial Management, 14(2), 273-294.

31. Flammer, C. (2013). Corporate social responsibility and shareholder reaction: The environmental awareness of investors. Academy of Management Journal, 56(3), 758-781. doi:

10.5465/amj.2011.0744

32. Häkkinen, T., Rekola, M., Ala-Juusela, M., \& Ruuska, A. (2016). Role of Municipal Steering in Sustainable Building and Refurbishment. Energy Procedia, 96, 650-661. doi: 10.1016/j.egypro.2016.09.123

33. Hanif, M., Hafeez, S., \& Riaz, A. (2010). Factors Affecting Customer Satisfaction. International Resource Journal of Finance and Economics, 60, 44-52.

34. Hilgers, D., \& Ihl, C. (2010). Citizensourcing: Applying the Concept of Open Innovation to the Public Sector. The International Journal of Public Participation, 4(1), 67-88.

35. Holmes, B. (2011, July 22). Citizen's engagement in policymaking and the design of public services. Retrieved from

http://www.aph.gov.au/About_Parliament/Parliamentary_Departments/Parliamentary_Library /pubs/rp/rp1112/12rp01

36. Horton, F., W. (Ed.) (2013). Overview of Information Literacy Resources Worldwide. Paris: UNESCO.

37. Humphreys, P. C. (1998). Improving Public Service Delivery. Retrieved from https://www.ipa.ie/_fileUpload/Documents/CPMR_DP_7_Improving_PublicService_Delivery.pdf

38. Ireland Ministry for the Environment, Heritage and Local Government (2004, January). Delivering Value for People Service Indicators in Local Authorities. Retrieved from 
https://www.yumpu.com/en/document/view/17734537/delivering-value-for-people-serviceindicators-in-local-authorities/3

39. Janowski, T. (2016). Implementing Sustainable Development Goals with Digital Government Aspiration-capacity gap. Government Information Quarterly, 33(4), 603-613. doi:

10.1016/j.giq.2016.12.001

40. Kamaruddin, S. M., Ahmad, P., \& Alwee, N. (2016). Community Awareness on Environmental Management through Local Agenda 21 (LA21). Procedia - Social and Behavioral Sciences, 222, 729-737. doi: 10.1016/j.sbspro.2016.05.234

41. Kasim, R., Ariffin, K., Martin, D., Rahman, I., Nagapan, S., \& Muniandy, S. (2014). A community happiness index: the experience from Indian community group in Kluang, Johor, Malaysia. Retrieved from http://eprints.uthm.edu.my/5411/1/A_Community_Happiness_Inde.pdf

42. Kernaghan, K. (2015). Serving seniors: Innovation and public sector service delivery. The Innovation Journal, 20(2), 1-18.

43. Khalid, S. A. (2010). Improving the Service Delivery: A case Study of Local Authority in Malaysia. Global Business Review, 11(1), 65-77. doi: 10.1177/097215090901100104

44. Kugonza, S., \& Mukobi, R. (2015). Public participation in services delivery projects in Buikwe District Local Government Uganda. Commonwealth Journal of Local Governance, 18, 127-147. doi: $10.5130 /$ cjlg.v0i18.4846

45. Loganathan, S., Iyengar, V., Chowdappa, S. \& Varghese, M. (2017). Population trends and public awareness of healthy and pathological ageing in India: A brief overview. Asian Journal of Psychiatry, 29(2), 49-53. doi: 10.1016/j.ajp.2017.04.012

46. Mansor, N., \& Razali, C. (2010). Customers' Satisfaction towards Counter Service of Local Authority in Terengganu, Malaysia. Asian Social Science, 6(8), 197-208. doi: 10.5539/ass.v6n8p197

47. Marinetto, M. (2003). Who Wants to be an Active Citizen? The politics and practice of community involvement. Sociology, 31(1), 103-120. doi: 10.1177/0038038503037001390

48. Mccann, E., Sullivan, S., Erickson, D., \& Young, R. (1997). Environmental Awareness, Economic Orientation, and Farming Practices: A Comparison of Organic and Conventional Farmers. Environmental Management, 21(5), 747-758. doi: 10.1007/s002679900064

49. Milinthajinda, P. (1999). Environmental Awareness of Municipality Members in Phetchaburi Province (Master thesis). Bangkok: Kasetsart University.

50. Mishler, W., \& Rose, I. (2001). What are the origins of political trust? Testing institutional and cultural theories in post-communist societies. Comparative Political Studies, 34(1), 30-62. doi: $10.1177 / 0010414001034001002$

51. Mokhlis, S., Aleesa, Y, \& Mamat, I. (2011). Municipal Service Quality and Citizen Satisfaction in Southern Thailand. Journal of Public Administration and Governance, 1(1), 122-137. doi: 10.5296/jpag.v1i1.717

52. Mpofu, M., \& Hlatywayo, C. K. (2015). Training and development as a tool for improving basic service delivery; the case of a selected municipality. Journal of Economics, Finance and Administrative Science, 20(39), 133-136. doi: 10.1016/j.jefas.2015.10.004

53. Newton, K. (2001). Trust, social capital, civil society, and democracy. International Political Science Review, 22(2), 201-214. doi: 10.1177/0192512101222004

54. Nyqvist, M., Walque, D., \& Svensson, J. (2014, August). Information is Power: Experimental Evidence on the Long-Run Impact of Community Based Monitoring. Retrieved from http://documents.worldbank.org/curated/en/739811468318587268/pdf/WPS7015.pdf

55. OECD. (2010). Strategies to Improve Rural Service Delivery. Paris: OECD Publishing. doi: 10.1787/9789264083967-en 
56. Ofoeze, H. G. A. (1999). Local government and development administration: Issues and cases. In O. Okereke (Ed.), Development Administration in Nigeria: Issues and Strategies (pp. 115-129). N. d.: Concave Publishers.

57. Osman, M. M., Bachok, S., Bakri, N. I. M., \& Harun, N. Z. (2014). Government Delivery System: Effectiveness of Local Authorities in Perak, Malaysia. Procedia-Social and Behavioral Sciences, 153, 452-462. doi: 10.1016/j.sbspro.2014.10.079

58. Osman, M. M., Jusoh, N. N., Bachok, S., \& Bakri, N. I. (2014). An assessment of local authority performance in delivering their services: Case study of Ipoh City Council. Journal of Architecture, Planning \& Construction Management, 4(2), 58-76.

59. Osman, M., Bakri, I., Bachok, S., Ibrahim, M., \& Mohamed, M. (2015). Assessing social welfare department service delivery system towards vulnerable and disadvantages group in Malaysia: a case study of Perak. Procedia Environmental Sciences, 28, 418-426. doi: 10.1016/j.proenv.2015.07.051

60. Palmer, J. A., Suggate, J., Robottom, I., \& Hart, P. (1999). Significant life experiences and formative influences on the development of adults' environmental awareness in the UK, Australia and Canada. Environmental Education Research, 5(2), 181-200. doi: 10.1080/1350462990050205

61. Perron, G. M., Côté, R. P., \& Duffy, J. F. (2006). Improving environmental awareness training in business. Journal of Cleaner Production, 14(6-7), 551-562. doi: 10.1016/j.jclepro.2005.07.006

62. Pinto, F. S., Costa, A. S., Figueira, J. R., \& Marques, R. C. (2016). The quality of service: An overall performance assessment for water utilities. Omega, 69, 115-125. doi:

10.1016/j.omega.2016.08.006

63. Pretorius, D., \& Schurink, W. (2007). Enhancing service delivery in local government : the case of a district municipality. Journal of Human Resource Management, 5(3), 19-29. doi: 10.4102/sajhrm.v5i3.148

64. Putnam, R., Leonardi, R., \& Nanetti, R. (1993). Making Democracy Work: Civic Traditions in Modern Italy. Princeton: Princeton University Press.

65. Ramachandra, A., \& Mansor, N. (2014). Sustainability of community engagement - in the hands of stakeholders? Education + Training, 56(7), 588-598. doi: 10.1108/ET-07-2014-0084

66. Razzaq, A. R., Hadi, M. Y., \& Mustafa, M. Z., Hamzah, A., Khalifah, Z., \& Mohamad, N. H. (2011). Local Community Participation in Homestay Program Development in Malaysia. Journal of Modern Accounting and Auditing, 7(12), 1418-1429.

67. Reyers, B., Stafford-Smith, M., Erb, K.-H., Scholes, R. J., \& Selomane, O. (2017). Essential Variables help to focus Sustainable Development Goals monitoring. Current Opinion in Environmental Sustainability, 26-27, 97-105. doi: 10.1016/j.cosust.2017.05.003

68. Rozilah, K., Alkali, M., \& Bala, I. (2014). Assessment of service user's experience on the facilities provision at UTHM Students' Residential Colleges. In 7th International Real Estate Research Symposium, 29-30 April, National Institute of Valuation, Putrajaya (pp. 1-12).

69. Sa, F., Rocha, A., Gonçalves, J., \& Cota, M. (2017). Model for the quality of local government online services. Telematics and Informatics, 34(5), 413-421. doi: 10.1016/j.tele.2016.09.002

70. Sajid, R. (2013). Measuring Customer Satisfaction and Loyalty in Relation to Online Shopping in Denmark (Master thesis). Retrieved from http://studylib.net/doc/18334526/measuringcustomer-satisfaction-and-loyalty-in-relation-to

71. Samsudin, S., Haron, S., \& Bakar, A. N. (2012). Operational Issues in Malaysian Local Authority: Value of Intermediaries Services toward Client Satisfaction. Procedia - Social and Behavioral Sciences, 68, 844-854. doi: 10.1016/j.sbspro.2012.12.271

72. Sandford, M. (2016). Local government: alternative models of service delivery. Retrieved from http://researchbriefings.files.parliament.uk/documents/SN05950/SN05950.pdf 
73. Sayers, R. (2006). Principles of Awareness-Raising for Information Literacy, a case study. Bangkok: UNESCO Bangkok.

74. Schwandt, T. A. (2015). The Sage dictionary of qualitative inquiry (4th ed.). London: Sage Publications.

75. Sengupta, M., Das, J., \& Maji, P. K. (2010). Environmental awareness and environment related behaviour of twelfth grade students in Kolkata: Effects of stream and gender. Anwesa, 5, 1-8.

76. Shaari, N., Ali, A., \& Ismail, N. (2015). Student's Awareness and Knowledge on the Implementation of Goods and Services Tax (GST) in Malaysia. Procedia Economics and Finance, 31, 269-279. doi: 10.1016/S2212-5671(15)01229-0

77. Shafie, F. (2013). Fm Help Desk: User Complaint System as an Fm Approach for Facilities Management Services in University TUN Hussein Onn Malaysia (UTHM) (Master thesis). Retrieved from http://eprints.uthm.edu.my/6870/1/GIPS_0700.pdf

78. Siddiquee, N. A. (2006). Public management reform in Malaysia: Recent initiatives and experiences. International Journal of Public Sector Management, 19(4), 339-358. doi: 10.1108/09513550610669185

79. Simioni, D. (2004). Air pollution and citizen awareness. Santiago: ECLAC.

80. Siong, H. C. (2008). Urban Governance and Rapid Urbanization Issues in Malaysia. Jurnal Alam Bina, 13(4), 1-24.

81. Stoner, K. (2002). Local Heroes: The Political Economy of Russian Regional Governance. Princeton: Princeton University Press.

82. Subhan, M., Ghani, A., \& Joarder, M. (2014). Urban community willingness to pay for improved solid waste management in Malaysian municipality: A choice modeling approach. Asian Social Science, 10(18), 122-136. doi: 10.5539/ass.v10n18p122

83. Sureshchandar, G. S., Rajendran, C., \& Anantharaman, R. N. (2002). The relationship between service quality and customer satisfaction: a factor specific approach. Journal of Services Marketing, 16(4), 363-379. doi: 10.1108/08876040210433248

84. Unegbu, V. E. (2013). Perceived Effect of Local Government Knowledge of Citizens Awareness of Local Government Income on its Utilization in Nigeria. Arabian Journal of Business and Management Review(Oman Chapter), 2(10), 40-50. doi: 10.12816/0002332

85. United Nations (2015). Sustainable Development Goals. Goal 3: Ensure healthy lives and promote well-being for all at all ages. Retrieved June 10, 2017, from http://www.un.org/sustainabledevelopment/health/

86. Uzunboylu, H., Cavus, N., \& Ercag, E. (2009). Using mobile learning to increase environmental awareness. Computers \& Education, 52(2), 381-389. doi: 10.1016/j.compedu.2008.09.008

87. Villamagna, A. M., Angermeier, P. L., \& Niazi, N. (2014). Evaluating opportunities to enhance ecosystem services in public use areas. Ecosystem Services, 7, 167-176. doi: 10.1016/j.ecoser.2013.09.002

88. Wang, I.-M., \& Shieh, C.-J. (2006). The relationship between service quality and customer satisfaction: the example of CJCU library. Journal of Information and Optimization Sciences, 27(1), 193-209. doi: 10.1080/02522667.2006.10699686

89. Wholey, J. S., \& Hatry, H. P. (1992). The case for performance monitoring. Public Administration Review, 52(6), 604-610. doi: 10.2307/977173

90. Wihlman, T. (2014). Innovation in Municipal Welfare Services. Mälardalens högskola: Mälardalen University.

91. Zamzami, Y. (2004). Neighborhood centers in Saudi society and realistic experience futuristic look. Publications Umm Al Qura University, 12(2), 153-167. 